\title{
First report of Myxobolus (Cnidaria: Myxozoa) spores in human feces in Brazil
}

\author{
Lisiane Lappe dos REIS ${ }^{1 *}$, Lucas Carvalho de JESUS ${ }^{1}$, Ormezinda Celeste Christo FERNANDES ${ }^{1}$, \\ David Eduardo BARROSO²

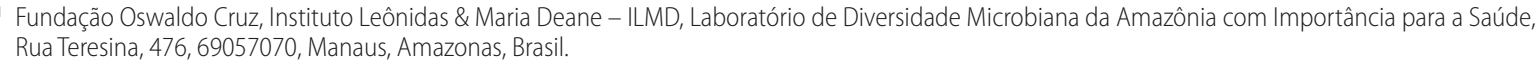

\begin{abstract}
Most species of Myxobolus (Cnidaria: Myxozoa) infect freshwater and marine fish, and cause sporozoosis. Passage of myxozoan parasites into human feces has been described occasionally. We examined fecal samples from 97 dwellers of a riverine community in Amazonas State (Brazil), which revealed Myxobolus sp. in 13 (13\%) samples. The discovery probably does not represent true parasitism as the myxospores - most likely ingested through the consumption of infected fish - were eliminated unchanged after passing through the gastrointestinal tract. This discovery represents the first report of this myxosporean in human fecal samples in Brazil.
\end{abstract}

KEYWORDS: myxosporean, human infection, Amazon, fish consumption

\section{Primeiro relato de esporos de Myxobolus (Cnidaria: Myxozoa) em fezes humanas no Brasil}

\section{RESUMO}

A maioria das espécies de Myxobolus (Cnidaria: Myxozoa) infecta principalmente peixes de água doce e marinhos, nos quais produz esporozoose. A passagem de parasitos mixozoários em fezes humanas tem sido ocasionalmente descrita. Nós examinamos amostras fecais de 97 moradores de uma comunidade ribeirinha no estado do Amazonas e identificamos Myxobolus sp. em 13 (13\%) delas. O achado provavelmente não representa um parasitismo verdadeiro, uma vez que os mixosporos - mais provavelmente ingeridos ao consumir peixes infectados - foram eliminados inalterados após a passagem pelo trato gastrointestinal. $\mathrm{O}$ achado representa o primeiro relato deste mixosporídeo em amostras fecais humanas no Brasil.

PALAVRAS-CHAVE: mixosporídeo, infecção humana, Amazonas, consumo de peixes

Myxozoans of the genus Myxobolus (Bütschli 1882) belong to the phylum Cnidaria, sub-phylum Myxozoa, class Myxosporea. Myxosporea is divided in the orders Bivalvulida and Multivalvulida. Bivalvulida includes the family Myxobolidae, which includes the genera Myxobolus and Henneguya (Okamura et al. 2015); the order Multivalvulida includes the genus Kudoa. These three genera have already been found in human feces.

Myxozoa exhibits complex life cycles with sexual reproduction occurring within invertebrate definitive hosts such as aquatic annelids or freshwater bryozoans (Eszterbauer et al. 2015). In addition, it infects intermediary vertebrate hosts such as fish, amphibians, and reptiles (Feist 2008; Eiras et al. 2005). It has also been found to infect endotherms: mammals (Prunesco et al. 2007) and birds (Bartholomew et al. 2008).
Transmission of myxozoans between invertebrate and vertebrate hosts is mediated by spores (Feist 2008). The morphology and morphometry of the spore or myxospore is the basis for the identification of Myxobolus species (Feist 2008). However, molecular studies have improved diagnostic tools for this myxosporean and have allowed the description of new species (Eiras et al. 2014).

Myxozoan infections in fish can result in substantial economic losses to aquaculture and fisheries, because they can cause damage to wild and farmed fish (Okamura et al. 2015). The infection by Myxobolus sp. is characterized by the formation of cysts in tissues with spores containing only two polar capsules. The presence of these cysts has been associated with gross deformities, tissue lesions, and organ malfunction, while in the gills, they can cause bleeding and swelling, which leads to a decreased surface for oxygen absorption (Feist 2008). 
Myxospores of Myxozoa have been incidentally found in human fecal samples, which were collected to investigate soil-transmitted helminthiases or intestinal diseases caused by protozoa of medical importance (Bradbury et al. 2015; McClelland et al. 1997). The presence of myxospores in human feces has been associated with ingestion of contaminated food or undercooked fish (Kawai et al. 2012). Infections in humans are considered accidental and without association with clinical manifestations (Bradbury et al. 2015; McClelland et al. 1997; Boreham et al. 1998). Although association of the parasite with gastrointestinal disorders has been reported (Moncada et al. 2001; Kawai et al. 2012), a causal relation with myxospores could not be established due to the concomitant presence of other enteric pathogens (Hessen and Zamzame 2004).

The parasite has been recorded in several Brazilian states (Adriano and Oliveira 2018), including the northern region (Amazonas and Pará states), which belongs to the Amazon region. Myxobolus was identified in the gills of Semaprochilodus insignis, known in Brazil as jaraqui (Eiras et al. 2005), in the blood of tambaqui, Colossoma macropomum (Maciel et al. 2011), in the subcutaneous tissue of pacu, Metynnis argenteus (Casal et al. 2006), in the skin and gills of pirarara, Phractocephalus hemioliopterus (Naldoni et al. 2018), in the gills of dourada, Brachyplatystoma rousseauxii (Zatti et al. 2018), and in ornamental fish endemic to the Amazon basin
(Mathews et al. 2016). However, Myxobolus sp. had never been reported in human feces in Brazil.

In October - November 2015, we carried out a field survey to evaluate the prevalence of intestinal parasites in inhabitants of a rural community in the state of Amazonas, in the Brazilian Amazon. The riverine community of Limão ( $03^{\circ} 11^{\prime} 0.99^{\prime \prime} S$, $\left.60^{\circ} 20^{\prime} 35.89^{\prime \prime} \mathrm{W}\right)$ is located in the municipality of Iranduba, at $52 \mathrm{~km}$ from the capital city of Manaus (Figure 1), on the shores of Limão Lake, near the Ariaú River. The climate is characterized by a rainy season, when annual flooding occurs, and a dry season. The study was approved by the Ethics Committee (CEUA) of Universidade Federal do Amazonas (protocol 41067414.6.0000.5020).

Fecal samples from 97 asymptomatic dwellers were collected in transport boxes and sent to the laboratory for analysis on the same day of delivery. The Hoffman concentration method was used for the parasitological analysis (Hoffman et al. 1934). In 13 (13\%) of the 97 samples, the parasitological examination of fecal samples resulted in the detection of Myxozoan spores, which were identified, based on their morphology and morphometry, as Myxobolus sp. (Figure 2). All samples presenting myxospores were from adults (22 to 71 years old) living in nine of the forty houses visited. Of these nine houses, three had 2 or 3 residents with positive samples $(\mathrm{n}=7)$.
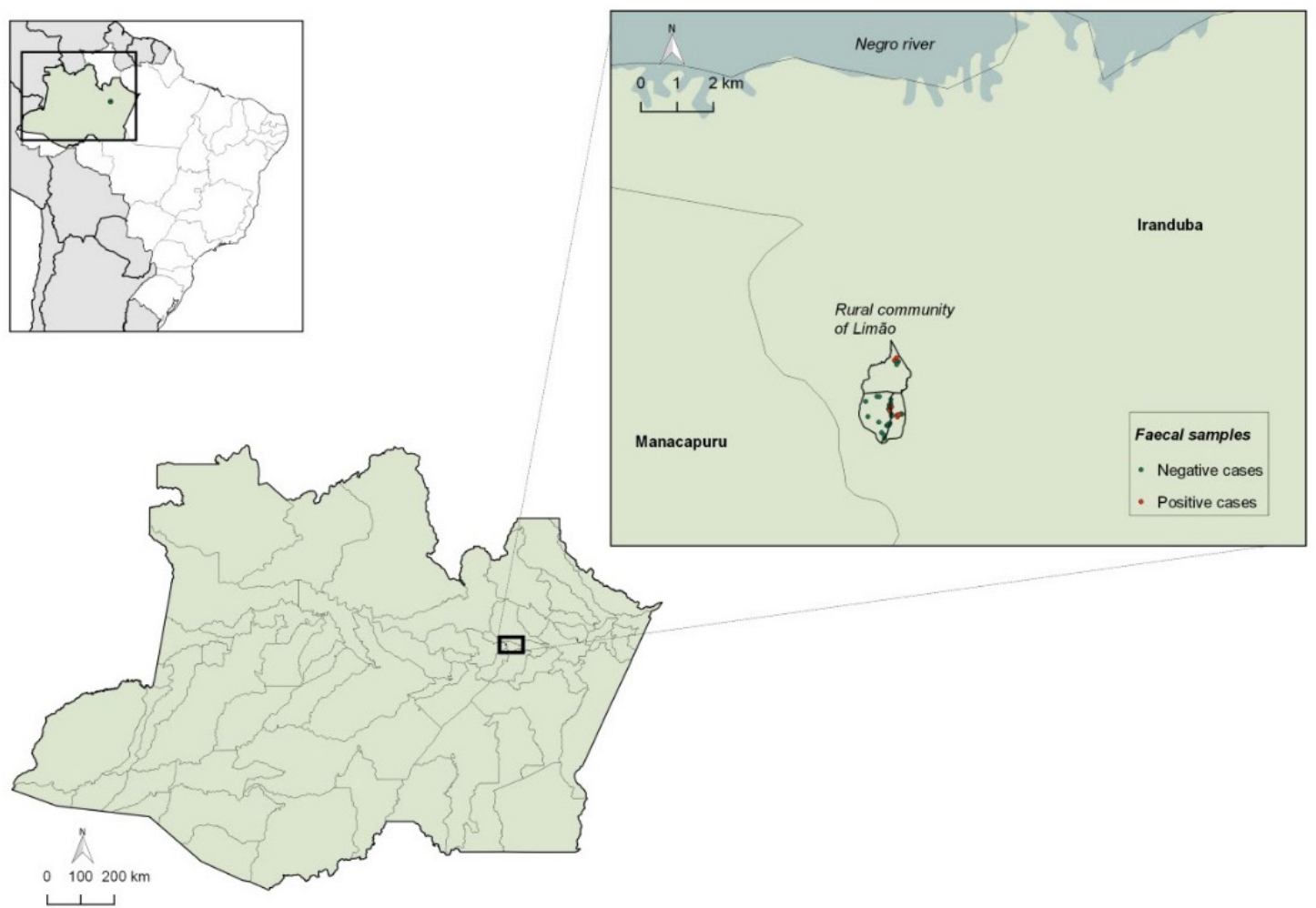

Figure 1. Location of the study site (Limão community) where Myxobolus sp. was recorded in human fecal samples (municipality of Iranduba, Amazonas state, Brazil). This figure is in color in the electronic version. 
The myxospores were micro-photographed using a digital system (Synoptics ${ }^{\mathrm{TM}}$, Cambridge, UK) coupled to an optical microscope (Leica DMTM1000, Frankfurt, Germany). The program Auto Montage 4.0 was used to obtain the final images. The spores of Myxobolus sp. were pyriform in shape and exhibited thick walls (Figure 2), were bilaterally symmetric, had one suture, and two polar capsules on each finer side of the central axis of the structure. Fresh spores (n $=13$ ) were 10 to $15 \mu \mathrm{m}$ in length and 7.5 to $10 \mu \mathrm{m}$ in width (average size, $12.7 \mu \mathrm{m}$ by $8.1 \mu \mathrm{m}$ ); the polar capsules were $3.7 \mu \mathrm{m}$ in length and $2.5 \mu \mathrm{m}$ in width.

In the Amazonas state, some studies have reported the occurrence of Myxobolus species infecting freshwater fish from farmed and natural environments, including Semaprochilodus insignis (jaraqui) (Eiras et al. 2005) and Corydoras melini (coridora) (Mathews et al. 2016). Consumption of fish in this state is very high, and is the main source of protein, particularly for people living in rural areas and in riverine communities (Lopes et al. 2016). Therefore, we assume that the spores identified in human feces were probably acquired through the consumption of infected fish and passed intact through the human digestive tract. Thus, the parasite probably did not establish an infection in humans that was able to cause disease.

However, Myxobolus was identified as the probable cause of diarrhea in an immunocompromised patient (Moncada et al. 2001). Another Myxozoa, Kudoa septempunctata, was responsible for outbreaks of food poisoning in Japan, caused by the consumption of raw fish (Kawai et al. 2012), and its sporoplasms may invade human epithelial cells (Ohnishi $e t$ al. 2013), though evidence of its pathogenicity is still weak (Chung and Bae 2017). Consuming raw, undercooked,

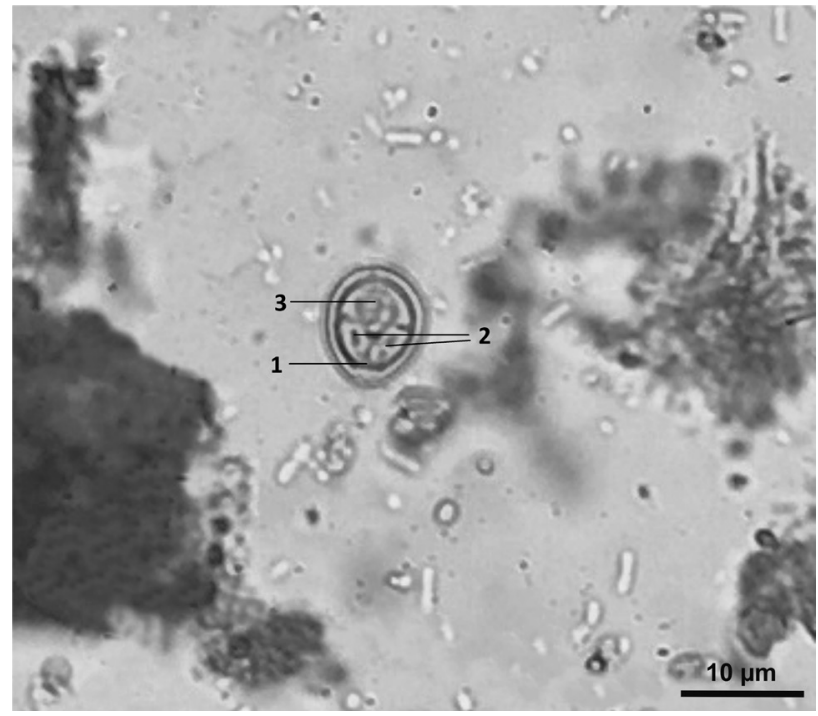

Figure 2. Microscopic image of a fresh spore of Myxobolus sp. in a human fecal sample from Limão community (Iranduba, Amazonas, Brazil): 1- suture; 2 - polar capsules; 3 - sporoplasm. or smoked fish can also transmit other parasites such as Diphyllobothrium latum, a cestode that causes dipyllobothriasis in humans (Emmel et al. 2006). Parasitic nematodes of fishes also can infect humans (Eiras et al. 2016).

We must also consider that the presence of myxospores may lead to erroneous diagnoses in pathology laboratories that examine human stools due to possible confounding interpretations with other structures (McClelland et al. 1997), or even leading to concerns of a new, previously unidentified protozoan species infecting humans rather than an artefact caused by the passage of fish parasitic spores.

At present, there is no evidence that the myxosporean life cycle involves a human host, and no stages of the parasite development besides the spores have been detected in humans (Hallet et al. 2015). Nevertheless, it is important to consider the possibility of myxosporean spores being passed into human feces while analyzing and diagnosing intestinal parasites, as well as detecting any change in the biology or ecology of myxosporidia involving human populations.

\section{ACKNOWLEDGMENTS}

We thank the Fundação de Amparo à Pesquisa do Estado do Amazonas - FAPEAM (protocol \# 22407UNI500.23909042014) for financial support, and Fernanda R. Fonseca, from the Centro de Suporte à Pesquisa, Instituto Leônidas \& Maria Deane - Fiocruz Amazônia, for the digital map.

\section{REFERENCES}

Adriano, E.A.; Oliveira, O.M.P. 2018. Myxosporea in Catálogo Taxonômico da Fauna do Brasil. PNUD. (http://fauna.jbrj. gov.br/fauna/faunadobrasil/152799). Accessed on 18 Sep 2018.

Bartholomew, J.L.; Atkinson, S.D.; Hallett, S.L.; Lowenstine, L.J.; Garner, M.M.; Gardiner, C.H. 2008. Myxozoan parasitism in waterfowl. International Journal of Parasitology, 38: 1199-1207.

Boreham, R.E.; Hendrick, S.; O’Donoghue, P. J.; Stenzel, D. J. 1998. Incidental finding of Myxobolus spores (Protozoa: Myxozoa) in stool samples from patients with gastrointestinal symptoms. Journal of Clinical Microbiology, 36: 3728-3730.

Bradbury, R.S.; Barbé, B.; Jacobs, J.; Jallow, A.T.; Camara, K.C.; Colley, M. et al. 2015. Enteric pathogens of food sellers in rural Gambia with incidental finding of Myxobolus species (Protozoa: Myxozoa). Transactions of the Royal Society of Tropical Medicine and Hygiene, 109: 334-339.

Casal, G.; Matos, E.; Azevedo, C. 2006. A new myxozoan parasite from the Amazonian fish Metynnis argenteus (Teleostei, Characidae): light and electron microscope observations. Journal of Parasitology, 92: 817-821.

Chung, Y.; Bae, J. 2017. Is there evidence that Kudoa septempunctata can cause an outbreak of acute food poisoning? Epidemiology and Health, 39:1-3.

Eiras, J.C. 2005. An overview on the myxosporean parasites in amphibians and reptiles. Acta Parasitologica, 50: 267-75. 
Eiras, J.C.; Malta, J.C.O.; Varella, A.M.B.; Pavanelli, G.C. 2005. Myxobolus insignis sp. n. (Myxozoa, Myxosporea, Myxobolide), a parasite of the Amazonian teleost fish Semaprochilodus insignis (Osteichthyes, Prochilodontidae). Memorias do Instituto Oswaldo Cruz, 100: 245-247.

Eiras, J.C.; Pavanelli, G.C.; Takemoto, R.M.; Yamaguchi, M.U.; Karkling, L.C.; Nawa, Y. 2016. Potential risk of fish-borne nematode infections in humans in Brazil - Current status based on a literature review. Food and Waterborne Parasitology, 5: 1-6.

Eiras, J.C.; Zhang, J.; Molnár, K. 2014. Synopsis of the species of Myxobolus Bütschli, 1882 (Myxozoa: Myxosporea, Myxobolidae) described between 2005 and 2013. Systematic Parasitology, 88: 11-36.

Emmel, V.E.; Inamine, E.; Secchi, C.; Brodt, T.C.Z.; Amaro, M.C.O.; Cantarelli, V.V.; Spalding, S. 2006. Diphyllobothrium latum: case report in Brazil. Revista da Sociedade Brasileira de Medicina Tropical, 39: 82-84.

Eszterbauer, E.; Atkinson, S.; Diamant, A.; Morris, D.; ElMatbouli, M.; Hartikainen, H. 2015. Myxozoan life cycles: practical approaches and insights. In: Okamura, B.; Gruhl, A.; Bartholomew, J.L. (Ed.). Myxozoan Evolution, Ecology and Development. Springer, Budapest, p.175-200.

Feist, S.W. 2008. Myxozoan diseases. In: Eiras, J., Segner, H.; Wahli, T.; Kapoor, B.G. (Ed.). Fish Diseases. Science Publishers, Enfield, p.615-682.

Hallet, S.L.; Atkinson, S.D.; Bartholomew, J. L.; Székely, C. 2015. Myxozoans exploiting homeotherms. In : Okamura, B., Gruhl, A., Bartholomew, J.L. (Ed.). Myxozoan Evolution, Ecology and Development. Springer, Budapest, p.125-135.

Hessen, E.M.; Zamzame, M.L. 2004. Myxobolus sp: a possible new opportunistic parasite in immunocompromised patients in Ismailia. Journal of the Egyptian Society of Parasitology, 34: 925-930.

Hoffman, W.A.; Pons, J.A.; Janer, J.L. 1934. The sedimentationconcentration method in Schistosomiasis mansoni. Puerto Rico Journal of Public Health, 9: 281-298.

Kawai, T.; Yahata, Y.; Kuroda, M.; Kumeda, Y.; Lijima, Y.; Kamata, Y.; Sugita-Konishi, Y.; Ohnishi, T. 2012. Identification of Kudoa septempunctata as the causative agent of novel food poisoning outbreaks in Japan by consumption of Paralichthys olivaceus in raw fish. Clinical Infectious Diseases, 54: 1046-1052.

Lopes, I.G.; Oliveira, R.G.; Ramos, F.M. 2016. Perfil do consumo de peixes pela população brasileira. Biota Amazônia, 6: 62-65.

Maciel, P.O.; Affonso, E.G.; Boijink, C.L.; Tavares-Dias, M.; Inoue, L.A.K. 2011. Myxobolus sp. (Myxozoa) in the circulating blood of Colossoma macropomum (Osteichthyes, Characidae). Revista Brasileira de Parasitologia Veterinária, 20: 82-84.
Mathews, P.D.; Naldoni, J.; Maia, A.A.; Adriana, E.A. 2016. Morphology and small subunit rDNA-based phylogeny of Ceratomyxa amazonensis n. sp. parasite of Symphysodon discus, an ornamental freshwater fish from Amazon. Parasitology Research, 115: 4021-4025.

Mathews, P.D.; Maia, A.A.M.; Adriano, E.A. 2016. Morphological and ultrastructural aspects of Myxobolus niger $\mathrm{n}$. sp. (Myxozoa) gill parasite of Corydoras melini (Siluriformes: Callichthyidae) from Brazilian Amazon. Acta Tropica, 158: 214-219.

McClelland, R.S.; Murphy, D.M.; Cone, D.K. 1997. Report of spores of Henneguya salminicola (Myxozoa) in human stool specimens: Possible source of confusion with human spermatozoa. Journal of Clinical Microbiology, 35: 2815-2818.

Moncada, L.I.; López, M.C.; Murcia, M.I.; Nicholls, S.; León, F.; Guío, O.L.; Corredor, A. 2001. Myxobolus sp., another opportunistic parasite in immunosuppressed patients? Journal of Clinical Microbiology, 39: 1938-1940.

Naldoni, J.; Maia, A.A.M.; Correa, L.L., Silva, M.R.M.D.; Adriano, E.A. 2018. New myxosporeans parasitizing Phractocephalus hemioliopterus from Brazil: morphology, ultrastructure and SSUrDNA sequencing. Diseases of Aquatic Organisms, 128: 37-49.

Ohnishi, T.; Kikuchi, Y.; Furusawa, H.; Kamata, Y.; SugitaKonishi, Y. 2013. Kudoa septempunctata invasion increases the permeability of human intestinal epithelial monolayer. Foodborne Pathogens and Disease, 10: 137-142.

Okamura, B.; Gruhl, A.; Bartholomew, J.L. 2015. An introduction to Myxozoan evolution, ecology and development. In: Okamura, B.; Gruhl, A.; Bartholomew, J.L. (Ed.). Myxozoan Evolution, Ecology and Development. Springer, Budapest p.1-20.

Prunesco, C.C.; Prunesco, P.; Pucek, Z.; Lom, J. 2007. The first finding of myxosporean development from plasmodia to spores in terrestrial mammals: Soricimyxum fegati gen. et sp. n. (Myxozoa) from Sorex araneus (Soricomorpha). Folia Parasitologica, 54: 159-164.

Zatti, S.A.; Atkinson, S.D.; Maia, A.A.M.; Corrêa, L.L.; Bartholomew, J.L.; Adriano, E.A. 2018. Novel Myxobolus and Ellipsomyxa species (Cnidaria: Myxozoa) parasiting Brachyplatystoma rousseauxii (Siluriformes: Pimelodidae) in the Amazon basin, Brazil. Parasitology International, 67: 612-621.

RECEIVED: 04/07/2018

ACCEPTED: 03/12/2018

ASSOCIATE EDITOR: Claudia Keller 